\title{
A Note on the Ninth Amendment to the Constitution of Lesotho
}

H 'Nyane*

\section{P.E.R}

Pioneer in peer-reviewed, open access online law publications

Author

Hoolo 'Nyane

Affiliation

University of Limpopo,

South Africa

Email

hoolo.nyane@ul.ac.za

Date Submission

6 August 2020

Date Revised

29 April 2021

Date Accepted

29 April 2021

Date published

12 May 2021

Editor Dr G Viljoen

How to cite this article

'Nyane H "A Note on the Ninth Amendment to the Constitution of Lesotho" PER / PELJ 2021(24) -

DOI

http://dx.doi.org/10.17159/17273781/2021/v24i0a8624

Copyright

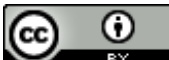

DOI

http://dx.doi.org/10.17159/1727-

3781/2021/v24i0a8624

\begin{abstract}
The Constitution of Lesotho has been amended nine times since its adoption in 1993. The latest amendment, styled the Ninth Amendment to the Constitution, was assented into law in May 2020 amidst great controversy. The Amendment makes fundamental changes to the Constitution. Its main thrust is to cushion parliament from early dissolutions necessitated by a motion of no confidence against the government. The Amendment has also introduced other significant changes to the Constitution. Those other changes are on the prorogation of parliament, the Prime Minister's resignation for personal reasons and the caretaker government. All these changes have been inspired by the country's constitutional problems since the advent of coalition politics in 2012. The purpose of this commentary is to critique these changes. The paper contends that the changes brought about by the Ninth Amendment can at best be regarded as interim rather than permanent measures, while the long-lasting constitutional reforms are being prepared for the country.
\end{abstract}

\section{Keywords}

Constitution of Lesotho; Ninth Amendment to the Constitution; vote of no confidence; dissolution of parliament; prorogation of parliament; caretaker government. 


\section{Introduction}

In May 2020 the King assented into law a private member's bill to amend the Constitution of Lesotho for the ninth time. The amendment is now styled "the Ninth Amendment to the Constitution of Lesotho". ${ }^{1}$ The Amendment is the culmination of a long drawn out controversy that started in October 2019 when the National Assembly adopted the motion to amend the Constitution to regulate the powers of the Prime Minister in the event of a successful motion of no confidence against the Prime Minister. ${ }^{2}$

In October 2019, when the National Assembly adopted a motion to amend the Constitution, the House was in unison - the motion was adopted unanimously. ${ }^{3}$ The prevailing mood amongst the members of parliament and the public at large at the time was that the motion would stabilise parliament and save the country the expenditure for the now regular snap elections. ${ }^{4}$ This was against the backdrop of three elections in the period between 2012 and 2017. The country went to snap elections in 2015 and 2017 because the Prime Minister advised early elections after losing the National Assembly's confidence. ${ }^{5}$

The initial consensual attitude towards the Bill notwithstanding, the actual enactment of the Bill has been mired in drama and controversy, which was

Hoolo 'Nyane. LLB (Lesotho) LLM (North-West) LLD (UNISA). Associate Professor and Head of Public and Environmental Law Department, School of Law, University of Limpopo, South Africa. E-mail: hoolo.nyane@ul.ac.za. ORCID: https://orcid.org/0000-0001-5674-8163.

1 Ninth Amendment to the Constitution Act 7 of 2020 (hereafter the Ninth Amendment).

2 Lesotho News Agency 2019 https://www.gov.Is/national-assembly-adopts-motionto-amendment-of-constitution/.

3 Lesotho News Agency 2019 https://www.gov.Is/national-assembly-adopts-motionto-amendment-of-constitution/.

$4 \quad$ The proposer of the motion, Lekhetho Rakuane (MP), is quoted as having said: "The motion will protect the economy of the country, promote stability as well as the banks and the pension fund in the country as the members will not take their pension monies early before their five-year term." See Lesotho News Agency 2019 https://www.gov.Is/national-assembly-adopts-motion-to-amendment-ofconstitution/. For an analysis of the cost that snap elections have on the country, see Mpaki $2017 \mathrm{http}: / /$ lestimes.com/what-price-democracy/.

$5 \quad$ In 2014 a motion of no confidence against the Prime Minister was filed, but it was never tabled and voted for. The Prime Minister just anticipated that since LCD, as the main partner in that coalition government, had already broken ranks, he would not survive a motion of no confidence. He then sent the Parliament to a nine-month prorogation cut short by international pressure on the condition that the Parliament would be dissolved and a snap election held in 2015. In 2017 the Prime Minister lost a vote of no confidence on the floor of the House, after which he advised the King to dissolve Parliament, and a fresh election was held in June 2017. Also see Sejanamane 2016 Afr Secur Rev 288. 
indicative of a clear division not only in parliament but even in the executive. This division manifested immediately after the National Assembly passed the Amendment on the $12^{\text {th }}$ March $2020 .^{6}$ The Prime Minister, who was opposed to the passage of the Bill, sent parliament to a three months' prorogation. ${ }^{7}$ The prorogation started on the $20^{\text {th }}$ March 2020 and was intended to end on the $19^{\text {th }}$ June 2020 . While the declared reason for the prorogation was to avoid large gatherings given the COVID-19 pandemic that was surging throughout the world, the real reason was that the Prime Minister sought to use the prorogation to abort the Bill. ${ }^{8}$ The prorogation was nullified by the Constitutional Court on the $17^{\text {th }}$ April 2020 on the basis, amongst others, that it was irrational. ${ }^{9}$ The nullification paved the way for the Senate to adopt the Amendment, which it did on the $28^{\text {th }}$ April 2020, thereby paving the way for the King to sign it into law. ${ }^{10}$ In the context that the Prime Minister could no longer advise the King to dissolve parliament when he has lost the confidence of the House ${ }^{11}$ due to the enactment of the Ninth Amendment, the then Prime Minister Thomas Thabane, who had lost the National Assembly's confidence, resigned on $19^{\text {th }}$ May $2020 .^{12}$

6 Contrary to the consensus that characterised the motion's passing in October 2019, the actual Amendment was passed by a vote of 93 out of 120 members of the National Assembly. The vote surpassed the two-thirds majority required to pass the Amendment in S 85 of the Constitution. See Ngatane 2020 https://ewn.co.za/2020/03/13/lesotho-votes-for-law-change-stripping-pm-ofpowers-to-dissolve-parliament/.

$7 \quad$ The parliament was prorogued in terms of Legal Notice 21 of 2020.

$8 \quad$ The Prime Minister was aware that prorogation not only ends the life of the business of Parliament - Bills that had not yet completed the legislative route at the time of prorogation, motions and questions - but "[i]t may also terminate sessional parliamentary committees and prevent committees from sitting or continuing an enquiry during the period of prorogation". Schleiter and Fleming 2020 Political Quarterly 642.

$9 \quad$ All Basotho Convention v Prime Minister (Constitutional Case No 0006/2020) 2020 LSHCONST 1 (17 April 2020) (hereafter All Basotho Convention v Prime Minister) para 20.

Mohloboli 2020 https://www.nasdaq.com/articles/lesothos-king-assents-to-billlimiting-pm-thabanes-powers-2020-05-07/.

Parliament did not necessarily pass a formal motion of no confidence in the Prime Minister. There was no formal motion of no confidence in the Prime Minister. Instead, three of the four parties in the former governing coalition, including the Prime Minister's party, All Basotho Convention (ABC), informed the Speaker of parliament, Sephiri Motanyane, of their withdrawal from the coalition. Aware that the government has lost the support of the majority of the members of the House, the Speaker announced on the $11^{\text {th }}$ May 2020 that the government had been dissolved. This was a bit odd because in terms of the Constitution the government can be removed only on a formal motion of no confidence. However, the reality of the matter is that the government no longer had support in the National Assembly. See Staff Reporter $2020 \mathrm{https}: / /$ lestimes.com/thabane-regime-collapses/.

12 Kabi and Motsoeli 2020 http://lestimes.com/thabane-resigns-pledges-support-formajoro/. 
While the main thrust of the Amendment is to cushion parliament from early dissolutions occasioned by an imagined or actual motion of no confidence against the government, ${ }^{13}$ it has introduced other significant changes to the Constitution. On top of regulation of the powers of the Prime Minister to advise dissolution, the other changes are to a prorogation of parliament, a resignation of the Prime Minister for personal reasons, and a caretaker government. The purpose of this commentary is to evaluate these changes critically. The paper contends that the Amendment has been unnecessarily hurried ahead of the other constitutional reforms the country is now involved in. At best, the changes brought about by the Ninth Amendment may be regarded as interim measures while the country is preparing holistic reforms to the Constitution.

\section{A vote of no confidence and a dissolution of parliament}

The animating principle of the formation of government in terms of the Constitution of Lesotho is that government must, at all material times, enjoy the confidence of the National Assembly. ${ }^{14}$ The House's confidence can be based on a single political party or a coalition of political parties. Lesotho's constitutional design is based on the British constitutional system and is reasonably settled. Section $87(2)$ of the Constitution embodies this principle as thus:

The King shall appoint as Prime Minister the member of the National Assembly who appears to the Council of State to be the leader of the political party or coalition of political parties that will command the support of a majority of the members of the National Assembly.

Equally, the Constitution gives parliament the power to withdraw confidence from the government of the day. ${ }^{15}$ Unlike the motion to remove the Speaker of the National Assembly, which requires the support of two-thirds of the

13 See Statement of Objects and Reasons of the Ninth Amendment. Furthermore, the sponsor of the motion, Lekhetho Rakuane MP, was quoted in the media as having said: "For a long time, I have observed a pattern of the rise and fall of governments which has plunged this country into costs (of holding elections) it could not even afford without the help of development partners. This happened while the state of affairs, in as far as service delivery and poverty are concerned, remained the same. I then sat and considered that there was need to do something about it... The law will assist in achieving long term political stability in the country. No more will governments collapse and snap elections be called on a whim... It also secures the completion of the national reforms process, which this country badly needs." Mohloboli $2020 \quad$ http://lestimes.com/rakuoane-speaks-on-constitutionalamendment/.

14 Bogdanor "A Hung Parliament" 19; Martin and Stevenson 2001 Am J Polit Sci 33; 'Nyane 2016 LDD 174.

15 See s 83 read with s 87 of the Constitution of Lesotho, 1993 (the Constitution). 
House,$^{16}$ the motion of no confidence in the government does not need a particular majority. It can be passed by an ordinary majority. ${ }^{17}$ The only procedural requirement for a motion of no confidence in government is that it shall not be effective "unless it proposes the name of a member of the National Assembly for the King to appoint in the place of the Prime Minister". ${ }^{18}$ Despite it being such a significant process, and the one that lies at the centre of government formation in Lesotho, the vote of no confidence is largely unregulated. The motion can be raised at any time. While there is an established practice in other Westminster designs that when the question about the confidence of the House in government is raised it must be resolved expeditiously, ${ }^{19}$ that is not necessarily the position in Lesotho. ${ }^{20}$

In terms of the old formulation, which the Ninth Amendment has now changed, once the House had passed a resolution of no confidence in government, the Prime Minister had two options - either to resign within three days or to advise the King to dissolve parliament. ${ }^{21}$ Ordinarily the King accepts the advice of the Prime Minister. ${ }^{22}$ Only under exceptional circumstances may the King reject the Prime Minister's advice to dissolve parliament. ${ }^{23}$ In particular, section 83(a) of the Constitution provided that the King may, acting on the advice of the Council of State, refuse the advice to dissolve parliament if he "considers that the Government of Lesotho can be carried on without dissolution and that a dissolution would not be in the interests of Lesotho". Ever since the adoption of the current Constitution in

16 Section 65(3)(e) of the Constitution provides that the office of the Speaker becomes vacant amongst other reasons "if he is removed from office by resolution of the National Assembly supported by the votes of two-thirds of all the members thereof". See s 83 read with s 87 of the Constitution.

18 See $\mathrm{s}$ 83(5) of the Constitution.

19 As Heard 2009 Constitutional Forum 9 observes, "serious doubts about parliament's confidence in the government must normally be settled in relatively short order. Precedents suggest that between a week and ten days is an appropriate length of time".

20 See s 83 read with s 87 of the Constitution.

21 See $\mathrm{s} 83(4)(\mathrm{b})$ of the Constitution.

Makenete v Lekhanya 1991-1996 LLR 486; Newman 2009 NJCL 217; Blackburn 1988 MLR 837.

$23 \quad$ Heard "Reserve Powers of the Crown" 87; Monahan Constitutional Law. The author captures the argument pointedly at 75-76: "As a general rule, the governor general should continue to act on the advice of the prime minister, assuming that he/she continued to enjoy the confidence of the House and should leave issues of legality or constitutionality to be adjudicated before the courts. ... There may be one exception to this rule arising where a government was persisting with a course of action that had been declared unconstitutional or illegal by the courts. In the event that the government sought the governor general's participation in a decision or action that had previously been declared unconstitutional, it might well be appropriate for the governor general to refuse to approve or participate in the illegal or unconstitutional conduct." 
1993, motions of no confidence and the resultant dissolutions of parliament have not been a common feature of Lesotho's constitutional practice. Even on those rare occasions when the opposition raised a motion of no confidence in government, they never succeeded. Motions of no confidence have started to be significant constitutional processes since 2012, when the country entered the fragile era of coalition politics. ${ }^{24}$ They started to be regular, and they destabilised parliament. In 2015 parliament had to be dissolved because Prime Minister Thomas Thabane's government had lost the confidence of the House due to a fall-out between the then main coalition partners - the All Basotho Convention $(A B C)$ and the Lesotho Congress for Democracy (LCD). ${ }^{25}$ The country had to go for an early election in February $2015,{ }^{26}$ hardly two years after the 2012 election. Similarly, the government elected in 2015 was removed through a vote of no confidence in March 2017 and the country held another election in June 2017. ${ }^{27}$

In a way, this created real mischief that needed to be addressed to stabilise parliament. The remedy deemed appropriate by parliament was the Ninth Amendment. The Amendment has removed dissolution as a readily available option to a Prime Minister who has lost a vote of no confidence. The only real option now available to the Prime Minister is resignation. The Prime Minister may still advise dissolution but only on condition that twothirds of the members of the National Assembly support such dissolution. ${ }^{28}$ The King may also dissolve parliament on the advice of the Council of State if, after sixty days since the resignation of the Prime Minister, the King does not find a person who will command the majority of the members of the National Assembly. ${ }^{29}$

To this end, the Amendment may have succeeded in warding off elections held almost every two years, thereby saving the taxpayers' money from being used on elections instead of the delivery of services. However, it is doubtful that the Amendment will stabilise parliament and governance as a whole. This is because the primary cause of parliamentary instability which is the vote of no confidence - remains largely unregulated, both substantively and procedurally. Substantively, the motion of no confidence in Lesotho still does not need any reasons in order for it to be passed. It still

\footnotetext{
$24 \quad$ 'Nyane "Advent of Coalition Politics" 77.

25 Weisfelder 2015 JAE 50; Booysen 2015 Electoral Studies 430.

26 Letsie 2015 JAE 81.

27 Southall 2017 Africa Yearbook 436.

28 It is unlikely that a Prime Minister who has already lost a vote of no confidence would be able to garner the two-thirds majority needed to advise the King to dissolve parliament. In the normal cause of events, the Prime Minister would have to resign. See s 3(c) of the Ninth Amendment to the Constitution Act 7 of 2020.
} 
depends on the political will of the members of parliament. Unlike in other countries where misconduct of a sitting head of government is dealt with by way of impeachment, ${ }^{30}$ in Lesotho there is no constitutional process of impeachment. Matters related to misconduct of the head of government who is the Prime Minister - are still treated as political. If the National Assembly wishes, it is at liberty to handle them through a vote of no confidence. ${ }^{31}$

Procedurally the motion of no confidence can be raised at any time during the life of parliament. That means that while its chances of dissolving parliament have been severely curtailed with the Ninth Amendment, it may still cause untold instability in government. ${ }^{32}$ Nothing prevents a vote of no confidence by the National Assembly from being tabled so often, even after the formation of a new government. Consequently, while the Amendment might have stabilised parliament in a way, the government remains vulnerable. It can be changed at any time. Therefore, it may be expected that the frequent turnover of governments may either remain unaffected by the Amendment or it may even be exacerbated. ${ }^{33}$

For instance, the Constitution of the Republic of South Africa, 1996 separates an impeachment process from a vote of no confidence. Both the procedures and the grounds also differ. On impeachment, s 89 thereof provides that:

"(1) The National Assembly, by a resolution adopted with a supporting vote of at least two thirds of its members, may remove the President from office only on the grounds of-

(a) a serious violation of the Constitution or the law;

(b) serious misconduct; or

(c) inability to perform the functions of office.

(2) Anyone who has been removed from the office of President in terms of subsection (1)(a) or (b) may not receive any benefits of that office, and may not serve in any public office".

On the motion of no confidence, $s 102$ thereof provides that:

"(1) If the National Assembly, by a vote supported by a majority of its members, passes a motion of no confidence in the Cabinet excluding the President, the President must reconstitute the Cabinet.

(2) If the National Assembly, by a vote supported by a majority of its members, passes a motion of no confidence in the President, the President and the other members of the Cabinet and any Deputy Ministers must resign."

See $\mathrm{s} 83$ of the Constitution.

For instance, in February 2021 the ruling party, All Basotho Convention, was reported to have considered recalling its own Prime Minister, Moeketsi Majoro, who had assumed office only in May 2020. See Mohloboli 2021 https://sundayexpress.co.Is/majoro-must-go-abc-mp/.

The Ninth Amendment may give members of parliament power to change government regularly without the involvement of the electorate. The Amendment may have promoted what may be termed "shortcut democracy", where the members of parliament regularly determine government without the involvement of the electorate. 
Furthermore, the Amendment has confused rather than improved the provisions of the Constitution relating to the dissolution of parliament. In terms of the Constitution, dissolution is a prerogative of the King exercisable on the Prime Minister's advice. ${ }^{34}$ In terms of section 83(1) of the Constitution, "[t]he King may at any time prorogue or dissolve parliament". Section 83(4) provides that "[i]n the exercise of his powers to dissolve or prorogue parliament, the King shall act in accordance with the advice of the Prime Minister". ${ }^{35}$ Section 83(2) provides that parliament "unless sooner dissolved, shall continue for five years from the date when the two Houses of parliament first meet after any dissolution and shall then stand dissolved". The import of these provisions has been that parliament in Lesotho has a lifespan of five years. However, it could be dissolved at any time by the King on the advice of the Prime Minister. Early dissolution became acute after 2012 when parliament had to be dissolved after an average period of two years; hence the elections in 2012, 2015 and 2017. This was clear mischief that needed to be addressed. In an attempt to remedy this mischief, the Ninth Amendment deleted all the three provisos to section 83(4) and replaced them with new provisos; ${ }^{36}$ without necessarily redrafting the whole of section 83(4).

The three newly introduced provisos to section 83(4) are to the effect that, firstly, if the National Assembly passes a resolution of no confidence in the government, the Prime Minister shall resign. ${ }^{37}$ Secondly, and much more problematically, the Amendment provides that "the Prime Minister shall not advise dissolution under this section unless the dissolution is supported by

See the Court of Appeal's decision in Phoofolo KC $v$ The Right Honourable Prime Minister (C of A (CIV) 17/2017) 2017 LSCA 8 (12 May 2017).

35

The subsection has three provisos as thus:

"Provided that -

(a) if the Prime Minister recommends a dissolution and the King considers that the Government of Lesotho can be carried on without a dissolution and that a dissolution would not be in the interests of Lesotho, he may, acting in accordance with the advice of the Council of State, refuse to dissolve parliament;

(b) if the National Assembly passes a resolution of no confidence in the Government of Lesotho and the Prime Minister does not within three days thereafter either resign or advise a dissolution the King may, acting in accordance with the advice of the Council of State, dissolve parliament; and

(c) if the office of Prime Minister is vacant and the King considers that there is no prospect of his being able within a reasonable time to find a person who is the leader of a political party or a coalition of political parties that will command the support of a majority of the members of the National Assembly, he may, acting in accordance with the advice of the Council of State, dissolve parliament." 
the resolution of two thirds majority of the members of the National Assembly". 38 The confusion brought about by this change is that ordinarily, the parliament of Lesotho can run for a period of five years unless dissolved at any time by the King upon the advice of the Prime Minister. The new change provides that a Prime Minister who has lost a vote of no confidence can no longer advise dissolution; his only option is resignation. However, the Amendment still suggests that if the Prime Minister can, despite having lost a vote of no confidence, secure a two-thirds majority, he can still advise dissolution. ${ }^{39}$ Furthermore, the section suggests - by providing that "the Prime Minister shall not advise dissolution under this section unless the dissolution is supported by the resolution of two thirds majority of the of the members of the National Assembly" - that every time dissolution needs to be done it must be done with the approval of two-thirds of the members of the National Assembly. This would mean that dissolution would still need a two-thirds majority for approval from parliament even at the end of the term. This is inelegant draftsmanship and a mechanism that has the potential to destabilise parliament.

The instability of parliament caused by early dissolutions is a problem that is fairly well established in parliamentary systems; it is not unique to Lesotho. ${ }^{40}$ The most straightforward way to remedy the problem has been to fix the term of a parliament and regulate the vote of no confidence. ${ }^{41}$ The United Kingdom's Fix-term Parliaments Act of 2011 provides a very safe blueprint in the interim. ${ }^{42}$ In the first instance, the law has removed the prerogative of dissolution from the monarch on the Prime Minister's advice; parliament dissolves ex lege after five years. ${ }^{43}$ An early election may be called under two circumstances. The first one is when parliament has passed a motion by a two-thirds majority "[t]hat there shall be an early parliamentary general election". ${ }^{44}$ The second one is when a motion of no confidence has been passed against the government and fourteen days have passed without the government securing the confidence of parliament. ${ }^{45}$

See s 3(b) of the Ninth Amendment.

See s 3(c) of the Ninth Amendment.

Baron 1998 Am Polit Sci Rev 593; Schleiter and Sukriti 2016 Gov Oppos 605-631.

Norton 2016 Parliamentary Affairs 3.

That is when the country continues to ponder on whether it retains the Westminsterbased parliamentary model or not.

Section 3(1) and (2) of the Fixed-term Parliaments Act, 2011.

Section 2(1)(b) of the Fixed-term Parliaments Act, 2011.

Section 2(3)(b) of the Fixed-term Parliaments Act, 2011. 
If the intention of the Ninth Amendment to the Constitution of Lesotho was to stabilise parliament, as it proclaims in its statement of objects and reasons, ${ }^{46}$ the best approach would be to review the whole of section 83 and make it more elegant and more precise in its draftsmanship along the lines of the United Kingdom model.

\section{The prorogation of parliament}

As a typical Westminster-based constitution, ${ }^{47}$ the Constitution of Lesotho provides for the prorogation of parliament. ${ }^{48}$ In terms of section $83(1)$, the King may at any time prorogue parliament. In terms of section $82(1)(a)$ of the Constitution, "the time appointed for the meeting of parliament after parliament has been prorogued shall be not later than twelve months from the end of the preceding session". Despite it being a potent political weapon that drifted from the King to the Prime Minister against parliament, ${ }^{49}$ the prerogative of prorogation was rarely used and has been less controversial in Lesotho since the return to constitutional democracy in 1993. It was not until 2012, when the country entered a period of coalition politics, that the prerogative of prorogation began to be controversially invoked by Prime Ministers. ${ }^{50}$ It then started to be a significant and controversial constitutional question in the country.

The mischief started in June 2014, hardly two years into a five-year parliamentary term that started in 2012. Prime Minister Thomas Thabane sent the parliament into a nine-month prorogation to pre-empt an impending motion of no confidence against his coalition government. ${ }^{51}$ His government had experienced a division as his Deputy, Mothejoa Metsing, had broken ranks. ${ }^{52}$ Consequently the government lost its majority in the National Assembly. To avoid being ousted on a vote of no confidence, the Prime

46 See the Statement of Objects and Reason to the Bill of the Ninth Amendment.

47 Macartney 1970 Parliamentary Affairs 121; Anckar 2007 Parliamentary Affairs 637. At 637 the author argues that the term "Westminster refers to the main characteristics of British parliamentary and governmental institutions". Also see De Smith New Commonwealth and its Constitutions. Also see De Smith $1961 \mathrm{~J}$ Commonw Polit Stud 2.

There is no statute providing prorogation or for other parliamentary affairs in Lesotho. The Parliament is regulated mainly in terms of the Constitution and the Standing Orders promulgated directly in terms of the Constitution. See ss 82,83 and 154 of the Constitution.

Tremblay 2010 Can Parliam Rev 16; Davison 2009 Law Now 13.

'Nyane "Advent of Coalition Politics" 77.

Weisfelder 2015 JAE 50.

Attorney General $v$ His Majesty the King (C of A (CIV) 13/2015; CONS/CASE/02/2015) 2015 LSCA 1 (12 June 2015). For a commentary, see 'Nyane 2015 Lesotho LJ 177. 
Minister prorogued parliament. Prorogation was invoked again by Prime Minister Thabane in March 2020. The circumstances of that prorogation were both dramatic and intriguing. On $20^{\text {th }}$ March 2020 at $18 \mathrm{hr} 00$, the Prime Minister wrote a letter to the King advising him to prorogue parliament, citing the COVID-19 pandemic as the reason for such prorogation. ${ }^{53}$ In the letter advising prorogation, the Prime Minister indicated that if the King did not comply with the advice by $21 \mathrm{~h} 00$ on the same day - which was effectively a three-hour ultimatum - the Prime Minister would invoke section 91(3) of the Constitution and prorogue parliament himself. Indeed, the King did not comply and the Prime Minister consequently went ahead and prorogued the parliament the same day. ${ }^{54}$

Following this mischief, which was a clear abuse of the system of the prorogation of parliament, it was deemed necessary that the time within which parliament may be on prorogation must be reduced. ${ }^{55}$ The Ninth Amendment changed the maximum duration of prorogation from twelve months to three months. However, the Amendment changed only the duration of the prorogation without changing the substance of prorogation itself, the reasons for which prorogation may be invoked. ${ }^{56}$ On both occasions - in 2014 and 2020 - Prime Minister Thabane not only exploited the long period provided by the constitution, ${ }^{57}$ but he also abused the openended nature of the provision relating to the reasons for prorogation. On both occasions he advised the King to prorogue parliament because he was facing a motion of no confidence in the House. ${ }^{58}$

Just like with a vote of no confidence, the Amendment does not regulate the substance and prorogation process; it only superficially reduces the maximum duration of a prorogation. ${ }^{59}$ This is despite the growing scholarly and judicial attitude within commonwealth countries that prorogation should not be abused to attain political ends. ${ }^{60}$ In the case of $R$ (on the application

53 However, the court found that the real reasons for prorogation were political. Two crucial political processes seem to have precipitated the decision to prorogue parliament: a) the National Assembly had just passed the Ninth Amendment to the Constitution, which, amongst other things, prevents a prime minister who has lost the confidence of the House from calling an early election; b) There was a pending motion of no confidence against the Prime Minister. See para 2 in the judgement. Legal Notice 21 of 2020.

Section 2(a) of the Ninth Amendment.

For possibilities of limiting the power to prorogue parliament, see Tremblay 2010 Can Parliam Rev 16.

$57 \quad$ Section $82(1)(\mathrm{a})$ of the Constitution.

58 Weisfelder 2015 JAE 50; Letsie 2015 JAE 81.

59 See $\mathrm{S} 2$ (b) of the Ninth Amendment.

$60 \quad$ Horgan 2014 Commonw Comp Polit 455; Tremblay 2010 Can Parliam Rev 16. 
of Miller) (Appellant) $v$ The Prime Minister, ${ }^{61}$ the Supreme Court of the United Kingdom invalidated the prorogation which was intended to circumvent parliament in the processes leading up to Britain's exit from the European Union. ${ }^{62}$ Similarly, the Constitutional Court of Lesotho in All Basotho Convention v The Prime Minister ${ }^{63}$ nullified the prorogation based on irrationality.

\title{
4 Death, retirement and resignation of the Prime Minister
}

The Amendment introduces a new section to the Constitution of Lesotho, which purportedly seeks to regulate parliament upon the death, retirement or resignation of the Prime Minister. The newly introduced section 90A (1) provides that:

\begin{abstract}
Notwithstanding the provisions of section 87(1) and (2), the King shall upon the death, retirement or resignation of the Prime Minister, appoint a member of the National Assembly who appears to be the leader of a political party or coalition of political parties that commands the majority of the members of the National Assembly, as Prime Minister, on the advice of the Speaker.
\end{abstract}

This section is superfluous; the Constitution, as it currently stands, adequately covers the situation of the resignation of the Prime Minister and how the vacancy will be filled. Section 152(1) of the Constitution provides that any person "who is appointed, elected or otherwise selected to any office established by this Constitution or any office of Minister or Assistant Minister established under this Constitution may resign from that office by writing under his hand addressed to the person or authority by whom he was appointed, elected or otherwise selected". The section provides for the resignation of any person who holds office under the Constitution, including the Prime Minister. There is, therefore, no need for a special provision regulating the resignation of the Prime Minister. Besides, the situation of a vacancy in the Prime Minister's office, whether as a result of a vote of no confidence or of his own volition, is adequately catered for. If a vacancy happens in the Prime Minister's office, section 87(2) - which empowers the King to appoint a member of the National Assembly who has the confidence of the House - immediately goes into operation. The new section 90A(1) has reproduced section 87(2) mutatis mutandis. There is no need for a new section to rehash an already fairly well established principle of government formation. The real question about section $87(2)$ is whether it might be

$61 \quad R$ (on the Application of Miller) (Appellant) $v$ The Prime Minister 2019 UKSC 41.

62 Craig 2020 Public Law 248.

63 All Basotho Convention v Prime Minister (Constitutional Case No 0006/2020) 2020 LSHCONST 1 (17 April 2020). 
improved to introduce an investiture vote after the elections to avoid the usual uncertainty after each election. ${ }^{64}$

Another anomaly with the new section is that it introduces the concept of the Prime Minister's retirement. This concept is not only alien to the constitutional design in Lesotho, but it is also unexplained. It is not clear from the new amendment what "retirement" means. In labour law, retirement connotes voluntary exit from employment because one has reached a certain age threshold established by law. ${ }^{65}$ It is different from resignation, which is unilateral and does not need any age threshold. It can happen at any time, without the need for reasons to be given. ${ }^{66}$ The Constitution of Lesotho does not provide for any age or term limit for a sitting Prime Minister. ${ }^{67}$ It is therefore inconceivable how a sitting Prime Minister may "retire", as the Amendment suggests.

\section{A caretaker government}

The Amendment further introduces new provisions relating to a caretaker government. ${ }^{68}$ The Constitution of Lesotho had no express provisions regulating a caretaker period and a caretaker government. In a parliamentary system such as that of Lesotho a caretaker period is the period between the dissolution of parliament and the formation of a new government. ${ }^{69}$ Where government changes without a dissolution of parliament, the caretaker period becomes "the transition between the termination of one government and the formation of another". ${ }^{70}$ The government that is in the office during this transitional period is called "a caretaker government". ${ }^{71}$ During this period, what the government can do or cannot do is regulated by a cluster of constitutional conventions called

64 Shale Lesotho Times; Schleiter, Belu and Hazell 2017 Political Quarterly 404; Rasmussen 1987 Parliamentary Affairs 139.

65 Baruch, Sayce and Gregoriou 2014 Personnel Review 464; Labuschagne and Bekker 2004 CILSA 40.

66 Pekeche $v$ Thabane (CIV/APN/208/98) 1998 LSCA 50 (20 May 1998); Lesotho Highlands Development Authority v Ralejoe (LAC/CIV/A/03/2006) 2007 LSLAC 5 (2 February 2007); Selloane Mahamo v Nedbank Lesotho Limited (LAC) (unreported) case number LAC/CIV/04/2011 (date unknown); Nthabiseng Mokoena $v$ Lesotho Post Bank (Pty) Ltd (LC/80/2013) 2013 LSLC 72 (13 October 2013). There is, however, a debate that is gathering momentum in the dialogue about the reforms, on imposing terms and an age limitation. See 'Nyane and Makhobole 2019 https://www.gov.ls/wp-content/uploads/2019/11/EXPERT-REPORT-OFCONSTITUTUIONAL-REFORMSFINAL-23-OCT-19.pdf.

68 Section 3(b) of the Ninth Amendment.

$69 \quad$ Simms "Westminster Norms and Caretaker Conventions" 94.

70 Schleiter and Belu 2015 Parliamentary Affairs 229.

71 Schleiter and Belu 2015 Parliamentary Affairs 229; Schleiter and Belu 2014 Political Quarterly 454. 
"caretaker conventions". ${ }^{72}$ These conventions are widely applied in other Commonwealth countries such as Canada, ${ }^{73}$ New Zealand and Australia. ${ }^{74}$ At the end of the day, the caretaker conventions are intended "to ensure that the country is never left without a fully functioning executive, and to prevent a government whose democratic mandate has expired from making decisions that will inappropriately bind the incoming government". ${ }^{75}$ To that end, they maintain a balance between ensuring that there is government at all material times and that a democratic mandate of a government in office during a caretaker period has expired. ${ }^{76}$ This balance is maintained against a backdrop of an animating principle of parliamentary democracies that government must be based on the confidence of parliament at all material times. Caretaker periods are normally very precarious for parliamentary democracies. As Schleiter and Belu contend:

The government's mandate to exercise its executive powers stems from its ability to command the confidence of parliament. However, there are points in every parliament's lifecycle when no government can lay claim to such support: between parliamentary dissolution and a general election; after a general election and before the new government is formed or when an incumbent government loses a confidence motion. During such periods a government must be in place. ${ }^{77}$

Three main conventions guide governments during a caretaker period. The first convention is that a caretaker government cannot resign. ${ }^{78}$ This convention is intended to ensure that a country can at no stage be left without an effective executive. ${ }^{79}$ The second is that a caretaker government is a government with severe limitations - it may not initiate new policy. It only maintains the status quo. ${ }^{80}$ This is the convention that acknowledges that although there is a need for an executive at all material times, a caretaker government lacks both a democratic mandate and the confidence of parliament. 81

Ever since independence from Britain in 1966, successive constitutions in Lesotho have never had express provisions regulating caretaker periods. It

Tiernan and Menzies Caretaker Conventions in Australasia.

Wilson 1995 Can Parliam Rev 12.

Boston et al 1998 VUW L Rev 629; Boston "Dynamics of Government Formation".

Schleiter and Belu 2015 Parliamentary Affairs 229.

Davis et al 2001 AJPA 11.

Schleiter and Belu 2015 Parliamentary Affairs 229.

Schleiter and Belu 2015 Parliamentary Affairs 229; Schleiter and Belu 2014 Political Quarterly 454.

79 Schleiter and Belu 2015 Parliamentary Affairs 229.

$80 \quad$ Schleiter and Belu 2015 Parliamentary Affairs 229.

81 For a discussion of the various perspectives about the powers of a caretaker government, see Klein 1977 Israel L Rev 271. 
has always been presumed that the caretaker periods would be based on British caretaker conventions. ${ }^{82}$ The demarcation of the caretaker period and the application of the caretaker conventions in Lesotho have been a subject of considerable controversy. At the very least, the Constitution provided for the period within which parliament must be convened after the election. ${ }^{83}$ The practice of governments in Lesotho during caretaker periods has been inconsistent and a cause of political instability. For instance, in 2012, after inconclusive elections, the then Prime Minister Mosisili resigned before the first sitting of parliament, alleging that it was only a procedural formality ${ }^{84}$ This resignation violated a longstanding convention that a caretaker government cannot resign. Similarly, a controversy erupted in January 2015 when Prime Minister Thomas Thabane advised the King to appoint the President of the Court of Appeal after the dissolution of parliament. ${ }^{85}$ The appointment was widely criticised for having been made during the caretaker period, in violation of the convention of maintaining the status quo during the coalition period. The Prime Minister contended that the constitution of Lesotho is silent about the caretaker conventions; the dissolution of parliament does not affect the constitutional powers of the Prime Minister. The appointment was challenged in the case of Attorney General $v$ His Majesty the King. ${ }^{86}$ While the case was still politically related to the grievance that the President of the Court of Appeal had been appointed during the caretaker period, its legal basis was not necessarily on caretaker conventions ${ }^{87}$ Instead, the issue in contention was whether

82 Schleiter and Belu 2015 Parliamentary Affairs 229.

83 Section $82(1)(b)$ of the Constitution provides that: "after parliament has been dissolved, the time appointed for the meeting of the National Assembly shall not be later than fourteen days after the holding of a general election of members of the National Assembly and the time appointed for the meeting of the Senate shall be such time as may be convenient after the nomination of one or more Senators in accordance with section 55 of this Constitution". This time has been changed by the Ninth Amendment to thirty days.

84 Staff Reporter 2012 https://mg.co.za/article/2012-05-30-lesotho-prime-ministersteps-down/.

85 Parliament was dissolved in December 2014 as part of the settlement done under the auspices of the Southern African Development Community (SADC).

86 Attorney General $v$ His Majesty the King (C of A (CIV) 13/2015; CONS/CASE/02/2015) 2015 LSCA 1 (12 June 2015).

87 Kananelo Mosito v Director of Public Prosecutions (C of A (CIV) 66/2015) 2016 LSCA 17 (29 April 2016), the court summed up the political reasons for the challenge thus: "The appellant's appointment was contentious from the outset, both politically and professionally. His appointment early last year during a political window preceding a general election was made on the recommendation of a man who was soon to lose office as Prime Minister to a bitter opponent. The incoming Prime Minister made plain that he thoroughly disapproved of the substance and timing of the appointment. Professionally the nomination was contentious as the appellant's elevation to such high judicial office straight from the ranks of the Bar was seen as arguably unduly swift." 
the Prime Minister could unilaterally - without involving the cabinet - advise the King to appoint the President of the Court of Appeal. ${ }^{88}$

Against this backdrop, the Amendment introduces the caretaker provisions to the Constitution of Lesotho. It introduces two principles related to the caretaker government. The first one is that if the Prime Minister resigns or dies, the Deputy Prime Minister will act as Prime Minister until a new Prime Minister is appointed. ${ }^{89}$ No time limit is provided for the appointment of a substantive Prime Minister. The second principle, which is derived from one of the settled caretaker conventions, is that "the powers of the Prime Minister or Deputy Prime Minister as a caretaker are limited in their function, serving only to maintain the status quo". ${ }^{90}$ In addition to the fact that the Amendment limits the powers of a caretaker government, the Amendment fails to provide clarity on the demarcation of caretaker periods. Under a Westminster system, ${ }^{91}$ there are three kinds of caretaker periods. The first one occurs when the Prime Minister resigns or dies without the dissolution of parliament. The Prime Minister may resign because of a successful motion of no confidence against him or out of his own volition. ${ }^{92}$ The second one is the period between dissolution and elections. In a parliamentary system, dissolution ends the life of parliament and, by extension, government. However, after dissolution, the government remains in office on a caretaker basis. What the government - both the Prime Minister and Ministers - can do during this period has been a subject of intense controversy in Lesotho. ${ }^{93}$ The third one is the period between elections and

$88 \quad$ 'Nyane 2015 Lesotho LJ 177.

89 See s 3(b) of the Ninth Amendment.

90 Section $87(7)$ of the Constitution.

$91 \quad$ While the term "Westminster" is generally understood to mean "based on the British system", there is a newly emerging scholarly view which challenges the widely held view that "Westminster" always means "British-based". See Russell and Ruxandra 2020 Gov Oppos 1. At 1, the authors say that "the term 'Westminster model', widely used in both the academic and practitioner literatures, is a familiar one. But detailed examination finds significant confusion about its meaning".

92 Twomey 2011 F L Rev 329.

93 In the case of Thulo $v$ Government Secretary (C of A (CIV) 2/2003) 2003 LSHC 50 (14 April 2003), the court of Appeal was concerned with whether a leader of the opposition remained in office after the dissolution of parliament. At para 6, the court said: "The Constitution does, however, expressly preserve certain specific 'offices' and provides that the holder of a particular office shall not be obliged to vacate his office when parliament dissolves, but only - 'if he ceases to be a member of the National Assembly [either House of Parliament] otherwise than by reason of a dissolution of parliament'. This applies to the office of the Prime Minister (section 87 (6) (a)), a Minister (section 87 (7) (a)), an Assistant Minister (section 93(2)), the Speaker of the National Assembly (section 63 (3) (a)) and the Deputy Speaker of the National Assembly (section 64(4) (a)). The Constitution preserves these offices in order that the government may remain in office to govern until the National Assembly first meets after the dissolution of parliament." 
the formation of a new government. ${ }^{94}$ This period is critical, too, because elections decide who will be able to form a government. Even on those occasions where the election is inconclusive, as it has been since 2012, coalition agreements immediately start after the election. Initially the Constitution provided that parliament must be convened fourteen days after the election. This period has been extended to thirty days by the Ninth Amendment, perhaps to accommodate the new reality of the bargaining in connection with forming a coalition. However, it is essential to note that the duration provided by the constitution - both the old and the new one relates to the convening of parliament to sit for the first time after the election, not for the government's formation. The period within which a government must be formed after an election remains unregulated.

These periods have varying constitutional and political implications. That notwithstanding, the Amendment seems to be based on the first type where the Prime Minister resigns without dissolution. It would be ideal for the amendment to cover all three types of caretaker period.

\section{Conclusion}

The foregoing discussion has analysed the three main changes that the newly enacted Ninth Amendment to the Constitution of Lesotho is seeking to make. The discussion has demonstrated that there are genuine mischiefs that the Amendment intends to remedy. However, the changes seem to fall far short of remedying the glaring challenges of the Constitution of Lesotho, which are longstanding but have just been laid bare by the country's entry into coalition politics in 2012. Rather than preferring the piecemeal approach to changes of the Constitution, the country needs to be so bold as to jettison the Westminster model in its entirety. ${ }^{95}$

The changes that the Ninth Amendment is bringing about are cosmetic. They make only minor alterations without affecting the fundamentals of the Westminster constitutional design. ${ }^{96}$ For instance, on the dissolution of parliament that comes after a vote of no confidence, the fundamental principles of the formation of government remain unaltered. The same applies to the prorogation and caretaker conventions. There may be an advantage in the piecemeal approach to the constitutional amendment - for

\footnotetext{
$94 \quad$ Keating 2002 AJPA 119.

95 'Nyane 2020 https://theconversation.com/lesotho-cant-afford-incremental-changesto-its-constitution-it-needs-a-complete-overhaul-140747/.

96 For the fundamentals of a Westminster design and how it has been transplanted into commonwealth countries, see Harding 2004 OUCLJ 143.
} 
reasons of urgency and simplicity - but there could also be disadvantages. The main disadvantage in adopting a piecemeal approach is that it gives a false impression - as it has done to Lesotho since the First Amendment, which was intended to stabilise and professionalise the army ${ }^{97}$ - that the main constitutional challenges are being addressed. To date the army continues to be a thorn in the flesh of constitutional democracy in Lesotho. ${ }^{98}$

Fortunately, the country has started a mega project of constitutional review. Ever since it started, it has passed two amendments to the constitution the Eighth Amendment and the Ninth Amendment. ${ }^{99}$ These two amendments are not necessarily the outcomes of the constitutional reform process. They are not only separate from it but they are also an undue distraction. The reform process in Lesotho is not very smooth, partly because of these interim changes. The Constitution of Lesotho is outmoded and has fundamental deficiencies, which make it one of the causes of instability in the country. The country needs a new constitution urgently and does not need a distraction. The country should avoid the temptation to take short cuts to the desired constitutional design - the short-term promises brought about by superficial changes like the Ninth Amendment to the Constitution. ${ }^{100}$

\section{Bibliography}

\section{Literature}

Anckar 2007 Parliamentary Affairs

Anckar D "Westminster Lilliputs? Parliaments in Former Small British Colonies" 2007 Parliamentary Affairs 637-654

Baron 1998 Am Polit Sci Rev

Baron DP "Comparative Dynamics of Parliamentary Governments" 1998 Am Polit Sci Rev 593-609

See the First Amendment to the Constitution of Lesotho Act 1 of 1996 . For a detailed analysis of the post-First Amendment analysis of the problems related to security in Lesotho, see Matlosa $2020 \mathrm{~J}$ Contemp Afr Stud 381; Matlosa and Pule 2001 Afr Secur Rev 62; Sejanamane 2016 Afr Secur Rev 288.

$98 \quad$ Matlosa $2020 \mathrm{~J}$ Contemp Afr Stud 381.

99 The Eighth Amendment was enacted in 2018. The Amendment introduced dual citizenship into Lesotho. See the Eighth Amendment to the Constitution of Lesotho Act 8 of 2018.

100 'Nyane 2020 https://theconversation.com/lesotho-cant-afford-incremental-changesto-its-constitution-it-needs-a-complete-overhaul-140747/. 
Baruch, Sayce and Gregoriou 2014 Personnel Review

Baruch Y, Sayce S and Gregoriou A "Retirement in a Global Labour Market: A Call for Abolishing the Fixed Retirement Age" 2014 Personnel Review 464-482

Blackburn $1988 M L R$

Blackburn $R$ "The Dissolution of Parliament: The Crown Prerogatives (House of Commons Control) Bill" 1988 MLR 837-840

Bogdanor "A Hung Parliament"

Bogdanor V "A Hung Parliament: A Political Problem, Not a Constitutional One" in Brazier A and Kalitowski S (eds) No Overall Control? The Impact of a "Hung Parliament" on British Politics (Hansard Society London 2008) 1526

Booysen 2015 Electoral Studies

Booysen S "The 2015 Parliamentary Elections in Lesotho" 2015 Electoral Studies 430-433

Boston "Dynamics of Government Formation"

Boston $\mathrm{J}$ "Dynamics of Government Formation" in Miller R (ed) New Zealand Government and Politics $5^{\text {th }}$ ed (Oxford University Press Melbourne 2010) 206-225

Boston et al 1998 VUW L Rev

Boston $\mathrm{J}$ et al "Caretaker Government and the Evolution of Caretaker Conventions in New Zealand" 1998 VUW L Rev 629-648

Craig 2020 Public Law

Craig PP "The Supreme Court, Prorogation and Constitutional Principle" 2020 Public Law 248-278

Davis et al 2001 AJPA

Davis G et al "Rethinking Caretaker Conventions for Australian Governments" 2001 AJPA 11-26

Davison 2009 Law Now

Davison CB "Prorogation: A Powerful Tool Forged by History" 2009 Law Now 13-15

De Smith New Commonwealth and its Constitutions

De Smith SA The New Commonwealth and its Constitutions (Stevens London 1964) 
De Smith 1961 J Commonw Polit Stud

De Smith SA "Westminster Export Model the Legal Framework of Responsible Government" 1961 J Commonw Polit Stud 2-16

Harding 2004 OUCLJ

Harding A "The 'Westminster Model' Constitution Overseas: Transplantation, Adaptation and Development in Commonwealth States" 2004 OUCLJ 143-166

Heard 2009 Constitutional Forum

Heard A "The Governor General's Decision to Prorogue Parliament: A Chronology and Assessment" 2009 Constitutional Forum 1-11

Heard "Reserve Powers of the Crown"

Heard A "The Reserve Powers of the Crown: The 2008 Prorogation in Hindsight" in Smith J and Jackson M (eds) The Evolving Canadian Crown (McGill-Queen's University Press Kingston 2012) 87-97

Horgan 2014 Commonw Comp Polit

Horgan GW "Partisan-motivated Prorogation and the Westminster Model: A Comparative Perspective" 2014 Commonw Comp Polit 455-472

Keating 2002 AJPA

Keating M "Caretaker Conventions Post Election" 2002 AJPA 119-120

Klein 1977 Israel L Rev

Klein C "The Powers of the Caretaker Government: Are they Really Unlimited?" 1977 Israel L Rev 271-287

Labuschagne and Bekker 2004 CILSA

Labuschagne BPS and Bekker JMT "Compulsory Retirement and Discrimination on the Grounds of Old Age" 2004 CILSA 40-64

Letsie $2015 \mathrm{JAE}$

Letsie TW "Lesotho's February 2015 Snap Elections: A Prescription that never Cured the Sickness" 2015 JAE 81-109

Macartney 1970 Parliamentary Affairs

Macartney WJ "African Westminster? The Parliament of Lesotho" 1970 Parliamentary Affairs 121-140

Martin and Stevenson $2001 \mathrm{Am} J$ Polit Sci

Martin L and Stevenson R "Government Formation in Parliamentary Democracies" 2001 Am J Polit Sci 33-50 
Matlosa $2020 \mathrm{~J}$ Contemp Afr Stud

Matlosa K "Pondering the Culture of Violence in Lesotho: A Case for Demilitarisation" 2020 J Contemp Afr Stud 381-398

Matlosa and Pule 2001 Afr Secur Rev

Matlosa K and Pule N "The Military in Lesotho" 2001 Afr Secur Rev 62-74

Monahan Constitutional Law

Monahan J Constitutional Law (Irwin Law Toronto 2006)

Newman 2009 NJCL

Newman WJ "Of Dissolution, Prorogation, and Constitutional Law, Principle and Convention: Maintaining Fundamental Distinctions During a Parliamentary Crisis" 2009 NJCL 217-229

Norton 2016 Parliamentary Affairs

Norton P "The Fixed-term Parliaments Act and Votes of Confidence" 2016 Parliamentary Affairs 3-18

'Nyane 2015 Lesotho LJ

'Nyane $\mathrm{H}$ "Commentary on the Case of Attorney General $v$ His Majesty the King and Others" 2015 Lesotho LJ 177-188

'Nyane 2016 LDD

'Nyane $\mathrm{H}$ "Formation of a Government in Lesotho in the Case of a Hung Parliament" 2016 LDD 174-191

'Nyane "Advent of Coalition Politics"

'Nyane $\mathrm{H}$ "The Advent of Coalition Politics and the Crisis of Constitutionalism in Lesotho" in Thabane M (ed) Towards Anatomy of Political Instability in Lesotho, 1966-2016 (Morija Printing Morija 2017) 77102

Rasmussen 1987 Parliamentary Affairs

Rasmussen $\mathrm{J}$ "Constitutional Aspects of Government Formation in a Hung Parliament" 1987 Parliamentary Affairs 139-153

Russell and Ruxandra 2020 Gov Oppos

Russell M and Ruxandra S "The Muddle of the 'Westminster Model': A Concept Stretched Beyond Repair" 2020 Gov Oppos 1-21 
Schleiter and Belu 2014 Political Quarterly

Schleiter $\mathrm{P}$ and Belu $\mathrm{V}$ "Avoiding another 'Squatter in Downing Street' Controversy: The Need to Improve the Caretaker Conventions before the 2015 General Election" 2014 Political Quarterly 454-461

Schleiter and Belu 2015 Parliamentary Affairs

Schleiter P and Belu V "The Challenge of Periods of Caretaker Government in the UK" 2015 Parliamentary Affairs 229-247

Schleiter and Fleming 2020 Political Quarterly

Schleiter $\mathrm{P}$ and Fleming TG "Parliamentary Prorogation in Comparative Context" 2020 Political Quarterly 641-648

Schleiter and Sukriti 2016 Gov Oppos

Schleiter P and Sukriti I "Constitutional Rules and Patterns of Government Termination: The Case of the UK Fixed-term Parliaments Act" 2016 Gov Oppos 605-631

Schleiter, Belu and Hazell 2017 Political Quarterly

Schleiter P, Belu V and Hazell R "Hung Parliaments and the Need for Clearer Rules of Government Formation" 2017 Political Quarterly 404-411

Sejanamane 2016 Afr Secur Rev

Sejanamane MM "Lesotho's 2015 Elections in the Context of an Ongoing Security Vacuum" 2016 Afr Secur Rev 288-302

Shale Lesotho Times

Shale S "Re-write or Re-read the Constitution?" Lesotho Times (9 April 2015) 13

Simms "Westminster Norms and Caretaker Conventions"

Simms M "Westminster Norms and Caretaker Conventions: Australian and New Zealand Transition Debates" in Hart P and Uhr J How Power Changes Hands (Palgrave Macmillan London 2011) 94-107

Southall 2017 Africa Yearbook

Southall R "Lesotho" 2017 Africa Yearbook 436-441

Tiernan and Menzies Caretaker Conventions in Australasia

Tiernan A and Menzies J Caretaker Conventions in Australasia: Minding the Shop for Government (ANU Press Canberra 2007) 
Tremblay 2010 Can Parliam Rev

Tremblay G "Limiting the Government's Power to Prorogue Parliament" 2010 Can Parliam Rev 16-17

Twomey 2011 F L Rev

Twomey A "Changing the Leader: The Constitutional Conventions Concerning the Resignation of Prime Ministers and Premiers" 2011 F L Rev 329-360

Weisfelder $2015 \mathrm{JAE}$

Weisfelder RF "Free Elections and Political Instability in Lesotho" 2015 JAE $50-80$

Wilson 1995 Can Parliam Rev

Wilson J "The Status of the Caretaker Convention in Canada" 1995 Can Parliam Rev 12-19

\section{Case law}

All Basotho Convention $v$ Prime Minister (Constitutional Case No 0006/2020) 2020 LSHCONST 1 (17 April 2020)

Attorney General $v$ His Majesty the King (C of A (CIV) 13/2015; CONS/CASE/02/2015) 2015 LSCA 1 (12 June 2015)

Kananelo Mosito v Director of Public Prosecutions (C of A (CIV) 66/2015) 2016 LSCA 17 (29 April 2016)

Lesotho Highlands Development Authority v Ralejoe (LAC/CIV/A/03/2006) 2007 LSLAC 5 (2 February 2007)

Makenete $v$ Lekhanya 1991-1996 LLR 486

Nthabiseng Mokoena v Lesotho Post Bank (Pty) Ltd (LC/80/2013) 2013 LSLC 72 (13 October 2013)

Pekeche v Thabane (CIV/APN/208/98) 1998 LSCA 50 (20 May 1998)

Phoofolo KC v The Right Honourable Prime Minister (C of A (CIV) 17/2017) 2017 LSCA 8 (12 May 2017)

$R$ (on the Application of Miller) (Appellant) $v$ The Prime Minister 2019 UKSC 41 
Selloane Mahamo $v$ Nedbank Lesotho Limited (LAC) (unreported) case number LAC/CIV/04/2011 (date unknown)

Thulo v Government Secretary (C of A (CIV) 2/2003) 2003 LSHC 50 (14 April 2003)

\section{Legislation}

Constitution of Lesotho, 1993

Constitution of the Republic of South Africa, 1996

Eighth Amendment to the Constitution of Lesotho Act 8 of 2018

First Amendment to the Constitution of Lesotho Act 1 of 1996

Fixed-term Parliaments Act, 2011

Legal Notice 21 of 2020

Ninth Amendment to the Constitution Act 7 of 2020

\section{Internet sources}

Kabi and Motsoeli 2020 http://lestimes.com/thabane-resigns-pledgessupport-for-majoro/

Kabi P and Motsoeli N 2020 Thabane Resigns, Pledges Support for Majoro http://lestimes.com/thabane-resigns-pledges-support-for-majoro/ accessed 8 August 2020

Lesotho News Agency 2019 https://www.gov.ls/national-assembly-adoptsmotion-to-amendment-of-constitution/

Lesotho News Agency 2019 National Assembly Adopts Motion to Amend Constitution https://www.gov.Is/national-assembly-adopts-motion-toamendment-of-constitution/ accessed 3 August 2020

Mohloboli 2020 http://lestimes.com/rakuoane-speaks-on-constitutionalamendment/

Mohloboli M 2020 Rakuoane Speaks on Constitutional Amendment http://lestimes.com/rakuoane-speaks-on-constitutional-amendment/ accessed 6th August 2020

Mohloboli 2020 https://www.nasdaq.com/articles/lesothos-king-assents-tobill-limiting-pm-thabanes-powers-2020-05-07/ 
Mohloboli M 2020 Lesotho's King Assents to Bill Limiting PM Thabane's Powers https://www.nasdaq.com/articles/lesothos-king-assents-to-billlimiting-pm-thabanes-powers-2020-05-07/ accessed 29 July 2020

Mohloboli $2021 \mathrm{https}$ ://sundayexpress.co.ls/majoro-must-go-abc-mp/ Mohloboli M 2021 Majoro must Go: ABC MP https://sundayexpress.co. Is/majoro-must-go-abc-mp/ accessed 16 March 2021

Mpaki 2017 http://lestimes.com/what-price-democracy/ Mpaki B 2017 What Price Democracy? Counting the Cost of the Upcoming Polls http://lestimes.com/what-price-democracy/ accessed 12 July 2020

Ngatane 2020 https://ewn.co.za/2020/03/13/lesotho-votes-for-law-changestripping-pm-of-powers-to-dissolve-parliament/

Ngatane M 2020 Lesotho Votes for Law Change Stripping PM of Powers to Dissolve Parliament https://ewn.co.za/2020/03/13/lesotho-votes-for-lawchange-stripping-pm-of-powers-to-dissolve-parliament/ accessed 6 August 2020

'Nyane $2020 \mathrm{https}: / /$ theconversation.com/lesotho-cant-afford-incrementalchanges-to-its-constitution-it-needs-a-complete-overhaul-140747/ 'Nyane H 2020 Lesotho can't Afford Incremental Changes to its Constitution: It Needs a Complete Overhaul https://theconversation.com/lesotho-cantafford-incremental-changes-to-its-constitution-it-needs-a-completeoverhaul-140747/ accessed 2 August 2020

'Nyane and Makhobole 2019 https://www.gov.ls/wp-content/uploads/ 2019/11/EXPERT-REPORT-OF-CONSTITUTUIONAL-REFORMSFINAL23-OCT-19.pdf

'Nyane H and Makhobole M 2019 Expert Report on Constitutional Reforms https://www.gov.ls/wp-content/uploads/2019/11/EXPERT-REPORT-OFCONSTITUTUIONAL-REFORMSFINAL-23-OCT-19.pdf accessed 6 August 2020

Staff Reporter 2012 https://mg.co.za/article/2012-05-30-lesotho-primeminister-steps-down/

Staff Reporter 2012 Lesotho PM Resigns after Losing Outright Majority https//mg.co.za/article/2012-05-30-lesotho-prime-minister-steps-down/ accessed 25 March 2021

Staff Reporter 2020 https://lestimes.com/thabane-regime-collapses/ Staff Reporter 2020 Thabane Regime Collapses https://lestimes. com/thabane-regime-collapses/ accessed 29 July 2020 


\section{List of Abbreviations}

ABC

Afr Secur Rev

AJPA

Am J Polit Sci

Am Polit Sci Rev

Can Parliam Rev

CILSA

Commonw Comp Polit

F L Rev

Gov Oppos

Israel L Rev

JAE

J Commonw Polit Stud

J Contemp Afr Stud

LCD

LDD

Lesotho LJ

MLR

NJCL

OUCLJ

VUW L Rev
All Basotho Convention

African Security Review

Australian Journal of Public Administration

American Journal of Political Science

American Political Science Review

Canadian Parliamentary Review

Comparative and International Law Journal of Southern Africa

Commonwealth and Comparative Politics

Federal Law Review

Government and Opposition

Israel Law Review

Journal of African Elections

Journal of Commonwealth Political Studies

Journal of Contemporary African Studies

Lesotho Congress for Democracy

Law, Democracy and Development

Lesotho Law Journal

Modern Law Review

National Journal of Constitutional Law

Oxford University Commonwealth Law Journal

Victoria University Wellington Law Review 